\title{
Potential of Spice-Derived Phytochemicals for Cancer Prevention
}

Author

Affiliation
Bharat B. Aggarwal, Ajaikumar B. Kunnumakkara, Kuzhuvelil B. Harikumar, Sheeja T. Tharakan, Bokyung Sung, Preetha Anand

Cytokine Research Laboratory, Department of Experimental Therapeutics, The University of Texas M. D. Anderson Cancer Center, Houston, Texas, USA

\author{
Key Words \\ - spice \\ - cancer \\ - chemoprevention \\ - phytochemicals \\ - molecular targets
}

received April 10, 2008

accepted May 6, 2008

Bibliography

DOI $10.1055 / \mathrm{s}-2008-1074578$

Planta Med 2008; 74: 1560

1569

๑) Georg Thieme Verlag KG

Stuttgart · New York

Published online July 8, 2008

ISSN 0032-0943

\section{Correspondence}

\section{Bharat B. Aggarwal, PhD}

Cytokine Research Laboratory

Department of Experimental

Therapeutics

The University of Texas

M. D. Anderson Cancer Center

1515 Holcombe Boulevard

Box 143

Houston

Texas 77030

USA

Tel.: +1/713/794/1817

Fax: $+1 / 713 / 745 / 6339$

aggarwal@mdanderson.org

\section{Abstract}

$\nabla$

Although spices have been used for thousands of years and are known for their flavor, taste and color in the food, they are not usually recognized for their medicinal value. Extensive research within the last two decades from our laboratory and others has indicated that there are phytochemicals present in spices that may prevent various chronic illnesses including cancerous, diabetic, cardiovascular, pulmonary, neurological and autoimmune diseases. For instance, the potential of turmeric (curcumin), red chilli (capsaicin), cloves (eugenol), ginger (zerumbone), fennel (anethole), kokum (gambogic acid), fenugreek (diosgenin), and black cumin (thymoquinone) in cancer prevention has been established. Additionally, the mechanism by which these agents mediate anticancer effects is also becoming increasingly evident. The current review describes the active components of some of the major spices, their mechanisms of action and their potential in cancer prevention.

\section{Abbreviations \\ $\nabla$ \\ ADT: anethole ditholethione \\ Bcl-3: $\quad$ B cell lymphoma protein-3 \\ CDK7: $\quad$ cyclin-dependent kinase 7 \\ CIAP: inhibitor of apoptosis \\ COX-2: $\quad$ cyclooxygenase-2 \\ DNA: deoxyribonucleic acid \\ EGF: epidermal growth factor \\ ELAM-1: endothelial leukocyte adhesion molecule- 1 \\ ERK or Erk: extracellular signal-regulated kinases}

$\begin{array}{ll}\text { GA: } & \text { gambogic acid } \\ \text { GSH: } & \text { glutathione } \\ \text { GST: } & \text { glutathione S-transferase } \\ \mathrm{H}_{2} \mathrm{O}_{2}: & \text { hydrogen peroxide } \\ \text { hTERT: } & \text { human telomerase reverse } \\ & \text { transcriptase }\end{array}$

ICAM-1: intercellular adhesion molecule-1

IKK: $\quad$ I $\kappa \mathrm{B} \alpha$ kinase

IL: interleukins

JAK: Janus kinases

5-LOX: 5-lipoxygenase

MM: multiple myeloma

MMP: matrix metalloproteinase

$\mathrm{NADH}$ nicotinamide adenine dinucleotide hydride

NF- $\kappa$ B: $\quad$ nuclear factor kappa B

NIK: $\quad$ NF- $\kappa B$ inducing kinase

NNK: nitrosamine 4-(methylnitrosamino)1-(3-pyridyl)-1-butanone

RANKL: receptor activator for nuclear factor $\kappa \mathrm{B}$ ligand

RHD: Rel homology domain

RTX: resiniferatoxin

STAT: $\quad$ signal transducer and activator of transcription

TNF: tumor necrosis factor

TNFR: $\quad$ TNF receptor

TQ: $\quad$ thymoquinone

TRAF: $\quad$ TNF receptor associated factor

UPA: $\quad$ urokinase plasminogen activator

VCAM: vascular cell adhesion molecule

VEGF: vascular endothelial growth factor

VEGFR2: VEGF receptor 2

\section{Introduction \\ $\nabla$}

It is generally believed that prevention is better than treatment. It is also an accepted reality that more than $90 \%$ of the cancers are preventable. Cigarette smoke, alcohol, environmental pollution, sunlight and diet have been shown to play a major role in causing cancer. How these agents 
cause cancer is also becoming evident. One of the major mediators of cancer that has emerged within last five years is chronic inflammation [1]. In contrast to acute inflammation, chronic inflammation is a low level inflammation that can persist over 20-30 years; thus eventually leading to cancer. Perhaps the best-known markers of chronic inflammation include inflammatory cytokines [such as tumor necrosis factor (TNF), receptor activator for nuclear factor $\kappa \mathrm{B}$ ligand (RANKL), interleukins (IL-1, IL-6, IL-8)] and chemokines, inflammatory enzymes [cyclooxygenase-2 (COX-2), 5-lipoxygenase (5-LOX), matrix metalloproteinase (MMP) and urokinase plasminogen activator (uPA)], adhesion molecules [intercellular adhesion molecule-1 (ICAM-1)], vascular cell adhesion molecule (VCAM-1), endothelial leukocyte adhesion molecule-1 (ELAM-1), and certain growth factors such as epidermal growth factor (EGF). Interestingly, all the mediators of inflammation are primarily regulated by two different transcription factors, nuclear factor kappa B (NF- $\kappa \mathrm{B})$ and signal transducer and activator of transcription-3 (STAT-3).

The process of tumorigenesis requires cellular transformation, hyper-proliferation, invasion, angiogenesis, and metastasis. Several genes that mediate these processes are regulated by the transcription factor NF- $\kappa$ B. The latter is activated by various carcinogens, inflammatory agents, and tumor promoters. Thus, agents which can suppress NF- $\kappa \mathrm{B}$ activation have the potential to suppress carcinogenesis. NF- $\kappa \mathrm{B}$ is a ubiquitous transcription factor that binds to a specific deoxyribonucleic acid (DNA) sequence as a dimeric complex composed of various combinations of members of the Rel/NF- $\kappa$ B family of polypeptides [2]. Family members of this transcription factor are 35 to $61 \%$ homologous to each other and have a Rel homology domain (RHD) of about 300 amino acids. NF- $\kappa B$ proteins are present in the cytoplasm of all cells, where they are kept in an inactive state by a family of anchorin domain-containing proteins, which includes $\mathrm{I} \kappa \mathrm{B} \alpha$, $\mathrm{I} \kappa \mathrm{B} \beta, \mathrm{I} \kappa \mathrm{B} \gamma, \mathrm{I} \kappa \mathrm{B} \varepsilon, \mathrm{B}$ cell lymphoma protein-3 (Bcl-3), p105, and $\mathrm{p} 100$. Under resting conditions, NF- $\kappa B$ consists of a heterotrimer of $\mathrm{p} 50, \mathrm{p} 65$, and $\mathrm{I} \kappa \mathrm{B} \alpha$ in the cytoplasm; only upon activation, do the p50 and p65 subunits translocate to the nucleus leading to the sequence of events. Most carcinogens, inflammatory agents, and tumor promoters, including cigarette smoke, phorbol ester, okadaic acid, hydrogen peroxide $\left(\mathrm{H}_{2} \mathrm{O}_{2}\right)$, and TNF, have been shown to activate NF- $\kappa \mathrm{B}$. The activation of NF- $\kappa \mathrm{B}$ involves the phosphorylation, ubiquitination and degradation of $\mathrm{I} \kappa \mathrm{B} \alpha$ and phosphorylation of $\mathrm{p} 65$, which, in turn, leads to the translocation of NF- $\kappa \mathrm{B}$ to the nucleus where it binds to specific response elements in the DNA. The phosphorylation of $\mathrm{I} \kappa \mathrm{B} \alpha$ is catalyzed by $\mathrm{I} \kappa \mathrm{B} \alpha$ kinase (IKK), which is essential for NF- $\kappa \mathrm{B}$ activation by most agents. NF- $\kappa \mathrm{B}$ has been shown to regulate the expression of several genes whose products are involved in tumorigenesis. These include antiapoptotic genes [e.g., inhibitor of apoptosis (cIAP), survivin, TNF receptor associated factor (TRAF), Bcl-2, and $\mathrm{Bcl}-\mathrm{xL}]$, genes encoding adhesion molecules (ICAM, VCAM), chemokines, inflammatory cytokines and cell cycle regulatory genes (e.g., cyclin D1 and c-myc).

Members of the STAT family of transcription factors regulate the expression of gene products involved in cell survival, proliferation, chemoresistance, and angiogenesis [3]. The activation of STATs involves the phosphorylation of a critical tyrosine residue by Janus kinases (JAK), or the Src family kinases, leading to dimerization of STAT monomers, nuclear translocation, and binding to specific DNA response elements in the promoters of target genes. Among the STATs, STAT3 is perhaps most intimately linked to tumorigenesis. Although STAT3 is activated by IL-6,
EGF, and other growth factors; constitutive activation of STAT3 has been discovered in a wide variety of tumors.

Dietary agents have been linked with prevention and therapy of cancer through a mechanism that is not well understood. We postulated that inflammation plays a major role in tumorigenesis through the activation of NF- $\kappa \mathrm{B}$ and STAT3 [1]. We also postulated that dietary agents mediate their effect through modulation of NF- $\kappa$ B and STAT-3 activation [4]. This factor regulates the expression of various genes that control apoptosis, viral replication, tumorigenesis, various autoimmune diseases, and inflammation. NF- $\kappa \mathrm{B}$ has been linked to the development of carcinogenesis for several reasons. Firstly, various carcinogens and tumor promoters have been shown to activate NF- $\kappa$ B. Secondly, activation of NF- $\kappa$ B has been shown to block apoptosis and promote proliferation. Thirdly, the tumor microenvironment can induce NF- $\kappa$ B activation. Fourthly, constitutive expression of NF$\kappa \mathrm{B}$ is frequently found in tumor cells. Fifthly, NF- $\kappa \mathrm{B}$ activation induces resistance to chemotherapeutic agents. Sixthly, several genes involved in tumor initiation, promotion, and metastasis are regulated by $N F-\kappa B$. Seventhly, various chemopreventive agents have been found to down-regulate the NF- $\kappa \mathrm{B}$ activation. All these observation suggest that NF- $\kappa \mathrm{B}$ could mediate tumorigenesis and thus can be used as a target for chemoprevention and for the treatment of cancer. Besides NF- $\kappa$ B, we have also targeted STAT3, another transcription factor that mediates tumorienesis. The evidence below shows that phytochemicals derived from spices are important inhibitors of NF- $\kappa$ B and STAT3 activation, and can suppress the expression of genes involved in carcinogenesis and tumorigenesis in vivo.

\section{Evidence That Spice-Derived Phytochemicals can Mediate Cancer Prevention \\ $\nabla$}

Phytochemicals derived from numerous spices have been linked with cancer prevention. This review, however, will focus on some of the major spice-derived phytochemicals as chemopreventive agents ( $\bullet$ Fig. 1 ).

\section{Capsaicin (red chilli)}

Capsaicin (trans-8-methyl- $N$-vanillyl-6-nonenamide) is a principal pungent ingredient of hot and red chili peppers that belong to the plant genus Capsicum (Solanaceae). In addition to alleviating neuropathic pain and itching in humans, capsaicin has exhibited anticancer effects in animal models, suppressing carcinogenesis of the skin, colon, lung, tongue, and prostate. The mechanism by which this vanilloid mediates its anticarcinogenic effects is not understood but it has been shown to alter the metabolism of carcinogens such as aflatoxin B1 and the tobacco-specific nitrosamine 4-(methylnitrosamino)-1-(3-pyridyl)1-butanone (NNK). In culture, capsaicin has been found to selectively suppress the growth of various human tumor cells [5], [6] including leukemic [7], [8], [9], gastric [10], hepatic [11], glioma [12], and prostate [13]. The roles of nicotinamide adenine dinucleotide hydride (NADH) oxidase activity, proteasome, COX, JNK, $\mathrm{NF}-\kappa \mathrm{B}$, peroxisome proliferators-activated receptor gamma, peroxynitrite and mitochondrial respiration have been implicated. Its immunosuppressive effects have been linked to its ability to suppress NF- $\kappa$ B activation. We examined the effect of capsaicin and its analogue, resiniferatoxin (RTX), on the activation of NF$\kappa \mathrm{B}$ induced by different agents including TNF [14]. The pretreatment of human myeloid cells with capsaicin blocked TNF-medi- 


\section{Spice}

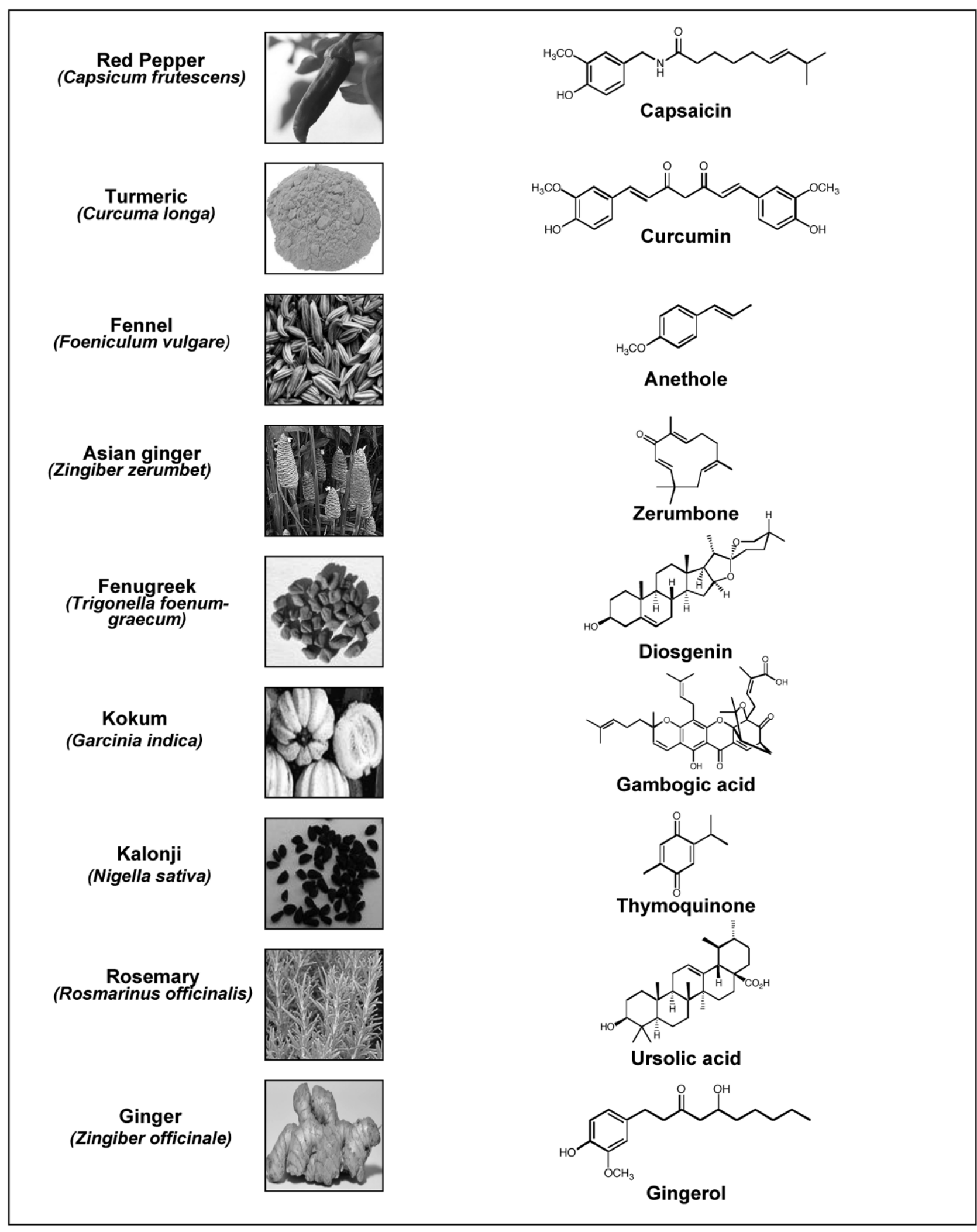

Fig. 1 Major spices and their active phytochemicals.

\section{Active phytochemical}

\section{Anethole}


tion but that mediated through okadaic acid was less effective, suggesting that there is a difference in the mechanism of activation of NF- $\kappa \mathrm{B}$ by different agents. Capsaicin treatment of cells also blocked the degradation of $\mathrm{I} \kappa \mathrm{B} \alpha$ and thus the nuclear translocation of the p65 subunit of NF- $\kappa \mathrm{B}$, which is essential for NF- $\kappa \mathrm{B}$ activation. TNF-dependent promoter activity of $\mathrm{I} \kappa \mathrm{B} \alpha$, which contains NF- $\kappa$ B binding sites, was also inhibited by capsaicin.

Because STAT-3 has been closely linked with tumorigenesis, we also investigated the effect of this vanilloid on the STAT3 pathway in human multiple myeloma (MM) cells [15]. We found that capsaicin inhibited constitutive activation of STAT3 in MM cells, with a minimal effect on STAT5. Capsaicin also inhibited IL-6-induced STAT3 activation. The activation of JAK1 and c-Src, implicated in STAT3 activation, were also inhibited by this vanilloid, with no effect on extracellular signal-regulated kinases (Erk1/2) activation. Pervanadate reversed the capsaicin-induced down-regulation of STAT3, suggesting the involvement of a protein tyrosine phosphatase. Capsaicin down-regulated the expression of the STAT3-regulated gene products, such as cyclin D1, Bcl-2, Bcl-xL, survivin, and VEGF. Finally, capsaicin induced the accumulation of cells in G1 phase, inhibited proliferation, and induced apoptosis, as indicated by caspase activation. Capsaicin also significantly potentiated the apoptotic effects of velcade and thalidomide in multiple myeloma cells. When administered intraperitoneally, capsaicin inhibited the growth of human multiple myeloma xenograft tumors in male athymic nu/ $n u$ mice. These results suggest that capsaicin is a novel blocker of the STAT3 activation pathway, with a potential role in the prevention and treatment of multiple myeloma and other cancers.

\section{Curcumin (turmeric)}

Curcumin is a component of the culinary spice turmeric, which is also often used in curry powder. Its active ingredient was first isolated in 1842 by Vogel. In 1910, Milobedzka determined that the structure was diferuloylmethane, and this compound was first synthesized in 1918 by Lampe and cocrystallized with 5LOX in 2003 by Skrzypczak-Jankun [16]. Extensive research over the last 50 years has indicated that this polyphenol can both prevent and treat cancer. It has also been demonstrated that curcumin can suppress tumor initiation, promotion, and metastasis. The anticancer potential of curcumin stems from its ability to suppress proliferation of a wide variety of tumor cells, to down-regulate transcription factors, to down-regulate the expression of COX-2, LOX, inducible nitric oxide synthase (iNOS), MMP-9, uPA, TNF, chemokines, cell surface adhesion molecules, and cyclin D1, to down-regulate growth factor receptors [such as epidermal growth factor receptor (EGFR) and human epidermal growth factor receptor (HER2)], and to inhibit the activity of cJun N-terminal kinase, protein tyrosine kinases, and protein serine/threonine kinases [17]. In several systems, curcumin has been described as a potent antioxidant and anti-inflammatory agent. The compound has been found to be pharmacologically safe: human clinical trials indicated no dose-limiting toxicity when administered at doses up to $10 \mathrm{~g} /$ day [18]. All of these studies suggest that curcumin has an enormous potential in prevention of and therapy for cancer. However, a better understanding of the mechanism would enhance the therapeutic potential of curcumin either alone or in combination with chemotherapy. We showed that curcumin could suppress NF- $\kappa$ B activation induced by TNF, phorbol ester, and $\mathrm{H}_{2} \mathrm{O}_{2}$ through suppression of $\mathrm{I} \kappa \mathrm{B} \alpha$ degradation [19]. How curcumin suppresses NF- $\kappa \mathrm{B}$ activation has also been investigated in detail. Curcumin inhibited
TNF-induced NF- $\kappa \mathrm{B}$-dependent reporter gene expression in a dose-dependent manner. Curcumin also suppressed NF- $\kappa$ B reporter activity induced by TNF receptor 1 (TNFR1), TNF receptor2 (TNFR2), NF- $\kappa$ B inducing kinase (NIK), IKK, and the p65 subunit of NF- $\kappa \mathrm{B}$. TNF-induced NF- $\kappa \mathrm{B}$-regulated gene products involved in cellular proliferation (COX-2, cyclin D1, c-myc), antiapoptosis (IAP1, IAP2, XIAP, Bcl-2, Bcl-xL, Bf1-1/A1, TRAF1, cFLIP) and metastasis (VEGF, MMP-9, ICAM-1) were also downregulated by curcumin. COX-2 promoter activity induced by TNF was abrogated by curcumin. We found that curcumin suppressed TNF-induced nuclear translocation of p65, which corresponded with the sequential suppression of $\mathrm{I} \kappa \mathrm{B} \alpha$ kinase activity, $\mathrm{I} \kappa \mathrm{B} \alpha$ phosphorylation, $\mathrm{I} \kappa \mathrm{B} \alpha$ degradation, p65 phosphorylation, p65 nuclear translocation, and p65 acetylation. Curcumin also inhibited TNF-induced AKT activation and its association with IKK. Glutathione and dithiothreitol reversed the effect of curcumin on TNF-induced NF- $\kappa$ B activation. Thus, it is likely that suppression of NF- $\kappa \mathrm{B}$ by curcumin plays a major role in its ability to prevent cancer.

Because curcumin has been shown to down-regulate the expression of Bcl-xL and cyclin D1 which are also regulated by activation of STAT3, whether curcumin can suppress constitutive or inducible activation of STAT3 was also investigated by us. We found that curcumin inhibited IL-6-induced STAT3 phosphorylation and consequent STAT3 nuclear translocation [20]. Curcumin had no effect on STAT5 phosphorylation but inhibited interferon- $\alpha$-induced STAT1 phosphorylation. The constitutive phosphorylation of STAT3 found in certain MM cells was also abrogated by treatment with curcumin [20]. Curcumin-induced inhibition of STAT3 phosphorylation was reversible. Compared with AG490, a well-characterized JAK2 inhibitor, the action of curcumin was more rapid ( $30 \mathrm{~min}$ vs. $8 \mathrm{~h}$ ) and it was a more potent $(10 \mu \mathrm{M}$ vs. $100 \mu \mathrm{M})$ inhibitor of STAT3 phosphorylation. Similarily, curcumin completely suppressed proliferation of MM cells whereas the same dose of AG490 had no effect. In addition, dexamethasone-resistant MM cells were found to be sensitive to curcumin.

\section{Anethole (fennel)}

Anethole, [1-methoxy-4-(1-propenyl)benzene], a chief constituent of fennel, anise, and camphor, has been shown to block both inflammation and carcinogenesis. This compound and related ones have striking metabolic effects. For example, anethole and its derivative, anethole dithiolethione (ADT), have been shown to increase the intracellular levels of glutathione (GSH) and glutathione S-transferase (GST) [21], [22], [23]. The structurally related compounds eugenol and isoeugenol, which are found in clove-oil, also modulate GSH metabolism [24]. These compounds act like antioxidants [25], [26], inhibit lipid peroxidation [24], [27], [28], and act as hydroxyl radical scavengers [29]. Because eugenol and isoeugenol inhibit arachidonic acid-induced thromboxane B2, they are extensively used as anti-inflammatory compounds [30], [31]. Besides their anti-inflammatory property, anethole and its analogues exhibit chemopreventive activities as indicated by suppression of the incidence and multiplicity of both invasive and non-invasive adenocarcinomas [32], [33], [34], [35], [36].

Since anethole exhibits anticarcinogenic, and anti-inflammatory properties, we proposed that the effects of anethole are mediated through modulation of TNF-induced cellular responses [37]. Our study showed that anethole inhibited TNF-induced activation of $\mathrm{NF}-\kappa \mathrm{B}, \mathrm{I} \kappa \mathrm{B} \alpha$ and degradation, and $\mathrm{NF}-\kappa \mathrm{B}$ reporter 
gene expression. Suppression of $\mathrm{I} \kappa \mathrm{B} \alpha$ phosphorylation and NF$\kappa \mathrm{B}$ reporter gene expression induced by TRAF2 and NIK suggests that anethole acts on $\mathrm{I} \kappa \mathrm{B} \alpha$ kinase. Anethole also blocked NF- $\kappa \mathrm{B}$ activation induced by a variety of other inflammatory agents. Anethole analogues eugenol and isoeugenol also blocked TNF signalling. Thus, the inhibitory effects of anethole on TNF induced cellular responses may explain its role in suppression of inflammation and carcinogenesis.

\section{Zerumbone (Asian ginger)}

Zerumbone [2,6,9,9-tetramethyl-(2E,6E,10E)-cycloundeca-2,6,10trien-1-one] was first isolated in 1956 from the essential oil of rhizomes of a wild ginger, Zingiber zerumbet Smith, which is widespread in Southeast Asia [38]. Over the years, a wide variety of activities have been assigned to this compound [39], [40], [41], [42], [43], [44], [45]. For instance, zerumbone has been found to suppress the proliferation of colon cancer [41], [45] and breast cancer [45], with minimal effects on normal cells [41]. Zerumbone has also been shown to suppress inflammation [39], suppress the initiation and promotion of skin tumors in mice [43], and prevent azoxymethane-induced aberrant crypt foci formation in rats [44]. This terpenoid has also been shown to suppress dextran sodium sulfate-induced colitis in mice [42] and inhibit the activation of the phorbol ester-induced Epstein-Barr virus [40]. Additional activities assigned to zerumbone are the suppression of superoxide and nitric oxide generation [46] and the down-regulation of COX-2 [47], IL-1 [42], and TNF [41], [42].

Several of these activities could be explained if zerumbone down-regulated NF- $\kappa \mathrm{B}$ activation, since zerumbone has proven effects on related activities. We found that zerumbone suppressed NF- $\kappa$ B activation induced by TNF, okadaic acid, cigarette smoke condensate, phorbol ester, and $\mathrm{H}_{2} \mathrm{O}_{2}$ and that the suppression was not cell type specific [48]. Interestingly, $\alpha$-humulene, a structural analogue of zerumbone lacking the carbonyl group, was completely inactive. Besides being inducible, constitutively active NF- $\kappa$ B was also inhibited. NF- $\kappa$ B inhibition by zerumbone correlated with sequential suppression of the $\mathrm{I} \kappa \mathrm{B} \alpha$ kinase activity, $\mathrm{I} \kappa \mathrm{B} \alpha$ phosphorylation, $\mathrm{I} \kappa \mathrm{B} \alpha$ degradation, p65 phosphorylation, p65 nuclear translocation, and p65 acylation. Zerumbone also inhibited the NF- $\kappa \mathrm{B}$-dependent reporter gene expression activated by TNF, TNFR1, TRADD, TRAF2, NIK, and IKK but not that activated by the p65 subunit of NF- $\kappa$ B. NF- $\kappa B-$ regulated gene products, such as cyclin D1, COX-2, MMP-9, ICAM-1, c-myc, survivin, IAP1, IAP2, XIAP, Bcl-2, Bcl-xL, Bfl-1/A1, TRAF1 and FLIP, were all down-regulated by zerumbone. This downregulation led to the potentiation of apoptosis induced by cytokines and chemotherapeutic agents. Zerumbone's inhibition of expression of these NF- $\kappa \mathrm{B}$-regulated genes also correlated with the suppression of TNF-induced invasion activity. These results indicated that zerumbone inhibits the activation of NF- $\kappa \mathrm{B}$ and $\mathrm{NF}-\kappa \mathrm{B}-$-regulated gene expression induced by carcinogens and that this inhibition may provide a molecular basis for the prevention and treatment of cancer by zerumbone.

\section{Diosgenin (fenugreek)}

Diosgenin, is a steroidal saponin found in a variety of plants [49], [50] including fenugreek (Trigonella foenum graecum), roots of wild yam (Dioscorea villosa), Solanum incanum Lloydia [51], Costus speciosus [52], and Solanum xanthocarpum [53]. Extracts from these plants have been traditionally used for the treatment of diabetes [54], [55], [56], hypercholestrolemia [57], [58], and gastrointestinal ailments [59], [60]. Research during the last decade has shown that diosgenin suppresses proliferation and induces apoptosis in cells of human colon carcinoma [60], [61], osteosarcoma [62], [63], leukemia [64], [65], [66], and human rheumatoid arthritis [67]. Antiproliferative effects of diosgenin are mediated through cell cycle arrest [62], disruption of $\mathrm{Ca}^{2+}$ homeostasis [65], [66], the activation of p53, release of apoptosis-inducing factor, and modulation of caspase-3 activity [68]. It also inhibits azoxymethane-induced aberrant colon crypt foci [60] and has been shown to inhibit intestinal inflammation [69] and modulate the activity of LOX [70] and COX-2 [62]. More recently, diosgenin has been shown to bind to the chemokine receptor CXCR3, which mediates inflammatory responses [71].

We reported that diosgenin inhibited RANKL-induced osteoclastogenesis, suppressed TNF-induced invasion, and blocked the proliferation of tumor cells, all activities known to be regulated by NF- $\kappa \mathrm{B}$ [72]. Diosgenin suppressed TNF-induced NF- $\kappa \mathrm{B}$ activation as determined by DNA binding, activation of $\mathrm{I} \kappa \mathrm{B} \alpha$ kinase, $\mathrm{I} \kappa \mathrm{B} \alpha$ phosphorylation, $\mathrm{I} \kappa \mathrm{B} \alpha$ degradation, p65 phosphorylation, and p65 nuclear translocation through inhibition of Akt activation. NF- $\kappa \mathrm{B}$-dependent reporter gene expression was also abrogated by diosgenin. TNF-induced expression of NF- $\mathrm{KB}$-regulated gene products involved in cell proliferation (cyclin D1, COX-2, cmyc), antiapoptosis (IAP1, Bcl-2, Bcl-xL, Bfl-1/A1, TRAF1 and cFLIP), and invasion (MMP-9) were also down-regulated by this saponin. Diosgenin also potentiated the apoptosis induced by TNF and chemotherapeutic agents. Thus diosgenin can suppress proliferation, inhibits invasion, and suppresses osteoclastogenesis through inhibition of NF- $\kappa \mathrm{B}$-regulated gene expression and enhances apoptosis induced by cytokines and chemotherapeutic agents.

\section{Gambogic acid (kokum)}

Gambogic acid (GA) is a naturally occurring brownish-to-orange resin called gamboges (also called kokkum), which is derived from Garcinia indica. It has a long history of medicinal use in Southeast Asia, and it is used as a folk medicine and coloring agent in China. Recent studies showed that GA can inhibit the growth of a wide variety of tumor cells, including cells of human hepatoma [73], breast cancer [9], gastric carcinoma [74], [75], [76], [77], and lung carcinoma [78]. Using cell- and caspasebased high-throughput screening assays, Zhang et al. identified GA as a potent inducer of apoptosis [9]. Studies have also indicated that GA suppresses the growth of human tumors, e.g., lung carcinoma and hepatoma [73]. How GA mediates these effects is not fully understood, but it has been shown to inhibit telomerase and telomerase reverse transcriptase mRNA expression [73], [76], [77], inhibit human telomerase reverse transcriptase (hTERT) promoter [76], suppress cyclin-dependent kinase 7 (CDK7)-mediated phosphorylation of CDC2/p34 [77], down-regulate $\mathrm{Bcl}-2$ [74], and interact with c-Myc [73]. A recent report suggests that GA mediates its apoptotic effects through its interaction with the transferrin receptor [79]. Because hTERT, c-Myc, and $\mathrm{Bcl}-2$ gene expression modulated by GA is regulated by NF$\kappa \mathrm{B}$ activation, it is possible that GA mediates its effects by modulating the NF- $\kappa B$ pathway. We found that GA enhanced apoptosis induced by TNF and chemotherapeutic agents, inhibited the expression of gene products involved in antiapoptosis (IAP1 and 2, Bcl-2, Bcl-xL, and TRAF1), proliferation (cyclin D1 and c-Myc), invasion (COX-2 and MMP-9) and angiogenesis (VEGF), all of which are known to be regulated by NF- $\kappa \mathrm{B}$ [80]. GA suppressed $\mathrm{NF}-\kappa \mathrm{B}$ activation induced by various inflammatory agents and carcinogens accompanied by the inhibition of TAK1/TAB1-medi- 
ated IKK activation, thus inhibiting $\mathrm{I} \kappa \mathrm{B} \alpha$ phosphorylation and degradation, suppressing p65 phosphorylation and nuclear translocation, and finally abrogating NF- $\kappa \mathrm{B}$-dependent reporter gene expression. The NF- $\kappa \mathrm{B}$ activation induced by TNFR1, TRADD, TRAF2, NIK, TAK1/TAB1 and IKK $\beta$ was also inhibited. The effect of GA was mediated through transferrin receptor as down-regulation of the receptor by RNA interference reversed its effects on NF- $\kappa \mathrm{B}$ and apoptosis. These results demonstrated that GA inhibits NF- $\kappa$ B signalling pathway.

Since angiogenesis is crucial for cancer development and other human diseases, whether and how GA inhibits angiogenesis was also investigated [81]. We discovered that GA inhibited angiogenesis in vitro and in vivo, and identified GA as a novel inhibitor of VEGF receptor 2 (VEGFR2). We demonstrated that GA significantly inhibited human endothelial cell proliferation, migration, invasion, tube formation, and microvessel growth with all antiangiogenesis characters. The effects of GA on cell proliferation, migration, and apoptotic activation were more effective in human endothelial cells than cancer cells, providing additional clues for cancer therapy of GA with low chemotoxicity. Using the xenograft mouse model, we found that GA inhibited tumor angiogenesis and prevented tumor growth by dramatically inhibiting angiogenesis. Furthermore, we demonstrated that GA directly inhibited the activation of VEGFR2 and suppressed its downstream kinases, such as Src, FAK, and AKT. Thus GA inhibits angiogenesis through down-regulation of VEGFR2 and its signalling pathways, and that GA is a viable drug candidate in antiangiogenesis and anticancer therapies.

\section{Thymoquinone (black cumin)}

Thymoquinone (TQ), the most abundant component of black cumin (Nigella sativa) seed oil, has been reported to exhibit antioxidant [82], [83], [84], anti-inflammatory, and chemopreventive [85], [86], [87] effects. For instance, TQ has been shown to suppress the proliferation of various tumor cells, including colorectal carcinoma, breast adenocarcinoma, osteosarcoma, ovarian carcinoma, myeloblastic leukemia, and pancreatic carcinoma [85], [88], [89], [90], [91], [92] while it is minimally toxic to normal cells [93]. In animal models, TQ has been shown to suppress acetic acid-induced colitis in rats [94], inhibit TNF- $\alpha$ production in murine septic peritonitis [95], and reduce carrageenan-induced paw edema in rats [96]. TQ has also been reported to enhance the antitumor activity of ifosfamide in Ehrlich ascites carcinoma-bearing mice [86], prevent cisplatin-induced nephrotoxicity in mice and rats [97], ameliorate benzopyrene-induced forestomach carcinogenesis [98], inhibit COX-2 expression and prostaglandin production in a mouse model of allergic airway inflammation [99], and protect against doxorubicin-induced cardiotoxicity in mice [100]. How TQ manifests these activities is not fully understood, but it has been shown to down-regulate the expression of Bcl-xL [89], COX-2 [99], iNOS [101], 5-LOX [102], TNF [103], and cyclin D1 [104], all known to be regulated by NF- $\kappa$ B.

Because numerous effects modulated by TQ can be linked to interference with $\mathrm{NF}-\kappa \mathrm{B}$ signalling, we investigated in detail the effect of this quinone on the NF- $\kappa$ B pathway [105]. As examined by DNA binding, we found that TQ suppressed TNF-induced NF$\kappa \mathrm{B}$ activation in a dose- and time-dependent manner, and inhibited NF- $\kappa$ B activation induced by various carcinogens and inflammatory stimuli. The suppression of NF- $\kappa \mathrm{B}$ activation correlated with sequential inhibition of the activation of $\mathrm{I} \kappa \mathrm{B} \alpha$ kinase, $\mathrm{I} \kappa \mathrm{B} \alpha$ phosphorylation, I $\mathrm{K} \mathrm{B} \alpha$ degradation, p65 phosphorylation, p65 nuclear translocation, and the NF- $\kappa \mathrm{B}$-dependent reporter gene expression. TQ specifically suppressed the direct binding of nuclear p65 and of the recombinant p65 to the DNA, and this binding was reversed by dithiothreitol. However, TQ did not inhibit p65 binding to DNA when cells were transfected with the p65 plasmid containing cysteine residue 38 mutated to serine. TQ also down-regulated the expression of NF- $\kappa \mathrm{B}$-regulated antiapoptotic (IAP1, IAP2, XIAP Bcl-2, Bcl-xL, and survivin), proliferative (cyclin D1, COX-2, and c-myc), and angiogenic (MMP-9 and VEGF) gene products. This led to potentiation of apoptosis induced by TNF and chemotherapeutic agents. Our results indicate that the anticancer and anti-inflammatory activities previously assigned to TQ may be mediated in part through the suppression of the NF- $\kappa \mathrm{B}$ activation pathway; and thus may have potential in the treatment of myeloid leukemia and other cancers.

We also recently reported that thymoquinone effectively inhibited human umbilical vein endothelial cell (HUVEC) migration, invasion, and tube formation [106]. Thymoquinone inhibited cell proliferation and suppressed the activation of AKT and ERK. Thymoquinone blocked angiogenesis in vitro and in vivo, prevented tumor angiogenesis in a xenograft human prostate cancer (PC3) model in mouse and inhibited human prostate tumor growth at low dosage with almost no chemotoxic side effects. Furthermore, we observed that endothelial cells were more sensitive to thymoquinone-induced cell apoptosis, cell proliferation and migration inhibition compared to PC3 cancer cells. Thymoquinone inhibited VEGF-induced ERK activation, but showed no inhibitory effects on VEGF receptor2 activation. Thus our results suggest that thymoquinone inhibits tumor angiogenesis and tumor growth, and could be used as a potential drug candidate for cancer therapy.

\section{Ursolic acid (rosemary)}

Ursolic acid ( $3 \beta$-hydroxy-urs-12-en-28-oic acid) is a pentacyclic triterpenoid (a member of the cyclosqualenoid family) derived from rosemary (Rosemarinus officinalis) and other plants. Ursolic acid has been shown to suppress tumorigenesis [107], inhibit tumor promotion [108], [109], [110], and suppress angiogenesis [111]. Several of these effects of ursolic acid are mediated through suppression of the expression of LOX, COX-2, MMP-9, and iNOS [112], [113], [114], [115], [116], [117], all of which are genes regulated by NF- $\kappa \mathrm{B}$. In addition, ursolic acid and its derivatives have been shown to induce apoptosis in a wide variety of cancer cells including breast carcinoma, melanoma, hepatoma, prostate carcinoma and acute myelogenous leukemia [118], [119], [120], [121], [122], [123], [124], through inhibition of DNA replication [125], activation of caspases [121], [123], [124], inhibition of protein tyrosine kinases [122], and induction of $\mathrm{Ca}^{2+}$ release [126], [127]. Another mechanism by which ursolic acid induces apoptosis involves down-regulation of the cellular inhibitor of apoptosis gene [121], another gene regulated by NF- $\kappa$ B. We found that ursolic acid suppressed NF- $\kappa$ B activation induced by various carcinogens including TNF, phorbol ester, okadaic acid, $\mathrm{H}_{2} \mathrm{O}_{2}$ and cigarette smoke [128]. These effects were not cell type specific. Ursolic acid inhibited $\mathrm{I} \kappa \mathrm{B} \alpha$ degradation, $\mathrm{I} \kappa \mathrm{B} \alpha$ phosphorylation, I $\kappa \mathrm{B} \alpha$ kinase activation, p65 phosphorylation, p65 nuclear translocation, and NF- $\mathrm{BB}-$ dependent reporter gene expression. Ursolic acid also inhibited NF- $\kappa \mathrm{B}$-dependent reporter gene expression activated by TNF receptor, TRADD, TRAF2, NIK, IKK, and $\mathrm{p} 65$. The inhibition of NF- $\kappa \mathrm{B}$ activation correlated with suppression of $\mathrm{NF}-\kappa \mathrm{B}-$ dependent cyclin D1, COX-2 and 
MMP-9 expression. These actions of ursolic acid may mediate its antitumorigenic and chemosensitizing effects.

We also found that ursolic acid inhibited both constitutive and IL-6-inducible STAT3 activation [129]. The suppression was mediated through the inhibition of activation of upstream kinases c-Src, JAK1, JAK2 and ERK1/2. Vanadate treatment reversed ursolic acid-induced down-regulation of STAT3, suggesting the involvement of a tyrosine phosphatase. Indeed, we found that ursolic acid induced the expression of tyrosine phosphatase SHP-1 protein and of mRNA. Moreover, knockdown of SHP-1 by siRNA suppressed the induction of SHP-1 and reversed the inhibition of STAT3 activation, thereby indicating the critical role of SHP-1 in the action of this triterpene. Ursolic acid down-regulated the expression of STAT3-regulated gene products such as, cyclin D1, Bcl-2, Bcl-xL, survivin, Mcl-1, and VEGF. Ursolic acid inhibited proliferation, induced apoptosis and the accumulation of cells in G1/G0 phase of cell cycle. This triterpenoid also significantly potentiated the apoptotic effects of thalidomide and velcade in MM cells. Thus ursolic acid is a novel blocker of STAT3 activation that may have a potential in prevention and treatment of various cancers.

\section{[6]-Gingerol (ginger)}

[6]-Gingerol, the major active component of ginger (Zingiber officinale), has also been linked with prevention of cancer through numerous mechanisms. [6]-Gingerol has been shown to inhibit the proliferation of a variety of cancer cell lines including prostate [130], gastric [131], and breast [132]. It inhibits neoplastic transformation in mouse epidermal cells [133], blocks VEGF-induced capillary-like tube formation in the mouse cornea, and suppresses lung metastasis of B16F10-melanoma [134]. Kim et al. [135] reported that topical application of [6]gingerol inhibited PMA-induced COX-2 expression in mouse skin by suppression of NF- $\kappa \mathrm{B}$. This phytochemical was found to suppress PMA-induced $\mathrm{I} \kappa \mathrm{B} \alpha$ degradation and translocation of p65 to nuclear in mouse skin by blocking of upstream kinase p38 MAPK. Recently, Lee et al [136] reported that [6]-ginerol exhibits antitumorigenic effects in human colorectal cancer cells through up-regulation of NSAID-activated gene-1 (NAG-1). This accompanies G1 cell cycle arrest by down-regulation of cyclin D1 that was mediated through the degradation of $\beta$-catenin by gingerol.

\section{Others}

Besides the spice phytochemicals described above, there are numerous others including cumin (Cuminum cyminum), coriander (Corriandrum sativum), cinnamon (Cinnamomum zeylanicum) and black pepper (Piper nigrum), however, there is very little known about their chemistry or the chemopreventive activities of the compounds derived from them. Two flavonoid glycosides, apigenin [137] and luteolin [138] derived from cumin, have been shown to exhibit cancer chemopreventive activities.

\section{Conclusions}

$\nabla$

From the description provided above it is clear that spice-derived phytochemicals have an enormous potential in the prevention and treatment of cancer. They can induce apoptosis, suppress proliferation of tumor cells, inhibit invasion and angiogenesis, and prevent even bone loss. These phytochemicals mediate their effects through multiple targets and yet pharmacologically they are highly safe. More animal studies and clinical trials are needed to prove the usefulness of these agents. Safety, inexpensive cost, years of intake by humans and their efficacy make them ideal agents. Therefore it is not too surprising to note that Vasco de Gama tried to look for these spices almost five centuries ago.

\section{Acknowledgements}

$\nabla$

Dr. Aggarwal is the Ransom Horne Professor of Cancer Research. This work was supported by grants from the Clayton foundation and from the Institutional NIH core grant (CA-16672).

\section{References}

1 Aggarwal BB, Shishodia S, Sandur SK, Pandey MK, Sethi G. Inflammation and cancer: how hot is the link? Biochem Pharmacol 2006; 72: 1605 21

2 Aggarwal BB. Nuclear factor-kappaB: the enemy within. Cancer Cell 2004; 6: $203-8$

3 Aggarwal BB, Sethi G, Ahn KS, Sandur SK, Pandey MK, Kunnumakkara $A B$ et al. Targeting signal-transducer-and-activator-of-transcription-3 for prevention and therapy of cancer: modern target but ancient solution. Ann N Y Acad Sci 2006; 1091: 151 - 69

4 Aggarwal BB, Shishodia S. Molecular targets of dietary agents for prevention and therapy of cancer. Biochem Pharmacol 2006; 71: 1397 421

5 Morre DJ, Chueh PJ, Morre DM. Capsaicin inhibits preferentially the NADH oxidase and growth of transformed cells in culture. Proc Natl Acad Sci U S A 1995; 92: 1831 - 5

6 Morre DJ, Sun E, Geilen C, Wu LY, de Cabo R, Krasagakis K et al. Capsaicin inhibits plasma membrane NADH oxidase and growth of human and mouse melanoma lines. Eur J Cancer 1996; 32A: 1995 - 2003

7 Kang SN, Chung SW, Kim TS. Capsaicin potentiates 1,25-dihydoxyvitamin D3- and all-trans-retinoic acid-induced differentiation of human promyelocytic leukemia HL-60 cells. Eur J Pharmacol 2001; 420: 83 90

8 Zhang J, Nagasaki M, Tanaka Y, Morikawa S. Capsaicin inhibits growth of adult T-cell leukemia cells. Leuk Res 2003; 27: 275-83

9 Zhang HZ, Kasibhatla S, Wang Y, Herich J, Guastella J, Tseng B et al. Discovery, characterization and SAR of gambogic acid as a potent apoptosis inducer by a HTS assay. Bioorg Med Chem 2004; 12: 309-17

$10 \mathrm{Kim}$ JD, Kim JM, Pyo JO, Kim SY, Kim BS, Yu R et al. Capsaicin can alter the expression of tumor forming-related genes which might be followed by induction of apoptosis of a Korean stomach cancer cell line, SNU-1. Cancer Lett 1997; 120: 235 - 41

11 Jung MY, Kang HJ, Moon A. Capsaicin-induced apoptosis in SK-Hep-1 hepatocarcinoma cells involves Bcl-2 downregulation and caspase-3 activation. Cancer Lett 2001; 165: 139-45

12 Qiao S, Li W, Tsubouchi R, Haneda M, Murakami K, Yoshino M. Involvement of peroxynitrite in capsaicin-induced apoptosis of C6 glioma cells. Neurosci Res 2005; 51: 175-83

13 Mori A, Lehmann S, O'Kelly J, Kumagai T, Desmond JC, Pervan $M$ et al. Capsaicin, a component of red peppers, inhibits the growth of androgen-independent, p53 mutant prostate cancer cells. Cancer Res 2006; 66: $3222-9$

14 Singh S, Natarajan K, Aggarwal BB. Capsaicin (8-methyl-N-vanillyl-6nonenamide) is a potent inhibitor of nuclear transcription factor-kappa B activation by diverse agents. J Immunol 1996; 157: 4412 - 20

15 Bhutani M, Pathak AK, Nair AS, Kunnumakkara AB, Guha S, Sethi G et al. Capsaicin is a novel blocker of constitutive and interleukin-6-inducible STAT3 activation. Clin Cancer Res 2007; 13: 3024- 32

16 Skrzypczak-Jankun E, Zhou K, McCabe NP, Selman SH, Jankun J. Structure of curcumin in complex with lipoxygenase and its significance in cancer. Int J Mol Med 2003; 12: $17-24$

17 Aggarwal BB, Kumar A, Bharti AC. Anticancer potential of curcumin preclinical and clinical studies. Anticancer Res 2003; 23: 363-98

18 Goel A, Kunnumakkara AB, Aggarwal BB. Curcumin as "Curecumin": from kitchen to clinic. Biochem Pharmacol 2008; 75: 787-809

19 Singh S, Aggarwal BB. Activation of transcription factor NF-kappa B is suppressed by curcumin (diferuloylmethane) [corrected]. J Biol Chem 1995; 270: $24995-5000$ 
20 Bharti AC, Donato N, Aggarwal BB. Curcumin (diferuloylmethane) inhibits constitutive and IL-6-inducible STAT3 phosphorylation in human multiple myeloma cells. J Immunol 2003; 171: 3863 - 71

21 Drukarch B, Schepens E, Stoof JC, Langeveld CH. Anethole dithiolethione prevents oxidative damage in glutathione-depleted astrocytes. Eur J Pharmacol 1997; 329: 259-62

22 Rompelberg CJ, Verhagen $H$, van Bladeren PJ. Effects of the naturally occurring alkenylbenzenes eugenol and trans-anethole on drug-metabolizing enzymes in the rat liver. Food Chem Toxicol 1993; 31: 637-45

23 Bouthillier L, Charbonneau M, Brodeur J. Assessment of the role of glutathione conjugation in the protection afforded by anethol dithiolthione against hexachloro-1,3-butadiene-induced nephrotoxicity. Toxicol Appl Pharmacol 1996; 139: 177-85

24 Stohs SJ, Lawson TA, Anderson L, Bueding E. Effects of oltipraz, BHA, ADT and cabbage on glutathione metabolism, DNA damage and lipid peroxidation in old mice. Mech Ageing Dev 1986; 37: 137- 45

25 Rajakumar DV, Rao MN. Dehydrozingerone and isoeugenol as inhibitors of lipid peroxidation and as free radical scavengers. Biochem Pharmacol 1993; 46: 2067-72

26 Ko FN, Liao CH, Kuo YN, Lin YL. Antioxidant properties of demethyldiisoeugenol. Biochim Biophys Acta 1995; 1258: 145 - 52

27 Nagababu E, Lakshmaiah N. Inhibition of microsomal lipid peroxidation and monooxygenase activities by eugenol. Free Radic Res 1994; 20: $253-66$

28 Mansuy D, Sassi A, Dansette PM, Plat M. A new potent inhibitor of lipid peroxidation in vitro and in vivo, the hepatoprotective drug anisyldithiolthione. Biochem Biophys Res Commun 1986; 135: 1015-21

29 Taira J, Ikemoto T, Yoneya T, Hagi A, Murakami A, Makino K. Essential oil phenyl propanoids. Useful as $\mathrm{OH}$ scavengers? Free Radic Res Commun 1992; 16: $197-204$

30 Naidu KA. Eugenol - an inhibitor of lipoxygenase-dependent lipid peroxidation. Prostaglandins Leukot Essent Fatty Acids 1995; 53: 381 - 3

31 Sharma JN, Srivastava KC, Gan EK. Suppressive effects of eugenol and ginger oil on arthritic rats. Pharmacology 1994; 49: 314-8

32 Reddy BS, Rao CV, Rivenson A, Kelloff G. Chemoprevention of colon carcinogenesis by organosulfur compounds. Cancer Res 1993; 53: 3493 -

33 Reddy BS. Chemoprevention of colon cancer by minor dietary constituents and their synthetic analogues. Prev Med 1996; 25: 48-50

34 Reddy BS. Chemoprevention of colon cancer by dietary administration of naturally-occurring and related synthetic agents. Adv Exp Med Biol 1997; 400B: $931-6$

35 Lubet RA, Steele VE, Eto I, Juliana MM, Kelloff GJ, Grubbs CJ. Chemopreventive efficacy of anethole trithione, $\mathrm{N}$-acetyl-L-cysteine, miconazole and phenethyl isothiocyanate in the DMBA-induced rat mammary cancer model. Int J Cancer 1997; 72: 95 - 101

36 al-Harbi MM, Qureshi S, Raza M, Ahmed MM, Giangreco AB, Shah AH. Influence of anethole treatment on the tumour induced by Ehrlich ascites carcinoma cells in paw of Swiss albino mice. Eur J Cancer Prev 1995; 4: $307-18$

37 Chainy GB, Manna SK, Chaturvedi MM, Aggarwal BB. Anethole blocks both early and late cellular responses transduced by tumor necrosis factor: effect on NF-kappaB, AP-1, JNK, MAPKK and apoptosis. Oncogene 2000; 19: $2943-50$

38 Kitayama T, Okamoto T, Hill RK, Kawai Y, Takahashi S, Yonemori S et al. Chemistry of zerumbone. 1 . Simplified isolation, conjugate addition reactions, and a unique ring contracting transannular reaction of its dibromide. J Org Chem 1999; 64: 2667-72

39 Ozaki Y, Kawahara N, Harada M. Anti-inflammatory effect of Zingiber cassumunar Roxb. and its active principles. Chem Pharm Bull (Tokyo) 1991; 39: $2353-6$

40 Murakami A, Takahashi M, Jiwajinda S, Koshimizu K, Ohigashi H. Identification of zerumbone in Zingiber zerumbet Smith as a potent inhibitor of 12-O-tetradecanoylphorbol 13-acetate-induced Epstein-Barr virus activation. Biosci Biotechnol Biochem 1999; 63: 1811 -2

41 Murakami A, Takahashi D, Kinoshita T, Koshimizu K, Kim HW, Yoshihiro $A$ et al. Zerumbone, a Southeast Asian ginger sesquiterpene, markedly suppresses free radical generation, proinflammatory protein production, and cancer cell proliferation accompanied by apoptosis: the alpha,beta-unsaturated carbonyl group is a prerequisite. Carcinogenesis 2002; 23: 795-802

42 Murakami A, Hayashi R, Tanaka T, Kwon KH, Ohigashi H, Safitri R. Suppression of dextran sodium sulfate-induced colitis in mice by zerumbone, a subtropical ginger sesquiterpene, and nimesulide: separately and in combination. Biochem Pharmacol 2003; 66: 1253-61
43 Murakami A, Tanaka T, Lee JY, Surh YJ, Kim HW, Kawabata K et al. Zerumbone, a sesquiterpene in subtropical ginger, suppresses skin tumor initiation and promotion stages in ICR mice. Int J Cancer 2004; 110: $481-90$

44 Tanaka T, Shimizu M, Kohno H, Yoshitani S, Tsukio Y, Murakami A et al. Chemoprevention of azoxymethane-induced rat aberrant crypt foci by dietary zerumbone isolated from Zingiber zerumbet. Life Sci 2001; 69: $1935-45$

45 Kirana C, McIntosh GH, Record IR, Jones GP. Antitumor activity of extract of Zingiber aromaticum and its bioactive sesquiterpenoid zerumbone. Nutr Cancer 2003; 45: $218-25$

46 Murakami A, Takahashi D, Koshimizu K, Ohigashi H. Synergistic suppression of superoxide and nitric oxide generation from inflammatory cells by combined food factors. Mutat Res 2003; $523-524$ : $151-61$

47 Murakami A, Matsumoto K, Koshimizu K, Ohigashi H. Effects of selected food factors with chemopreventive properties on combined lipopolysaccharide- and interferon-gamma-induced IkappaB degradation in RAW264.7 macrophages. Cancer Lett 2003; 195: 17-25

48 Takada Y, Murakami A, Aggarwal BB. Zerumbone abolishes NF-kappaB and IkappaBalpha kinase activation leading to suppression of antiapoptotic and metastatic gene expression, upregulation of apoptosis, and downregulation of invasion. Oncogene 2005; 24: 6957-69

49 Puri HS, Jefferies TM, Hardman R. Diosgenin and yamogenin levels in some Indian plant samples. Planta Med 1976; 30: 118-21

50 Djerassi C. Drugs from Third World plants: the future. Science 1992; 258: $203-4$

51 Segal R, Milo-Goldzweig I, Zaitschek DV. Diosgenin and yomogenin from Solanum incanum. Lloydia 1977; 40: 604

52 Dasgupta B, Pandey VB. A new Indian source of diosgenin (Costus speciosus). Experientia 1970; 26: 475-6

53 Heble MR, Narayanaswami S, Chadha MS. Diosgenin and beta-sitosterol: isolation from solanum xanthocarpum tissue cultures. Science 1967: 161: 1145

54 Madar Z, Abel R, Samish S, Arad J. Glucose-lowering effect of fenugreek in non-insulin dependent diabetics. Eur J Clin Nutr 1988; 42: 51 - 4

55 Sharma RD, Raghuram TC, Rao NS. Effect of fenugreek seeds on blood glucose and serum lipids in type I diabetes. Eur J Clin Nutr 1990; 44: $301-6$

56 Gupta A, Gupta R, Lal B. Effect of Trigonella foenum-graecum (fenugreek) seeds on glycaemic control and insulin resistance in type 2 diabetes mellitus: a double blind placebo controlled study. J Assoc Physicians India 2001; 49: 1057-61

57 Valette G, Sauvaire Y, Baccou JC, Ribes G. Hypocholesterolaemic effect of fenugreek seeds in dogs. Atherosclerosis 1984; 50: 105-11

58 Sauvaire Y, Ribes G, Baccou JC, Loubatieeres-Mariani MM. Implication of steroid saponins and sapogenins in the hypocholesterolemic effect of fenugreek. Lipids 1991; 26: $191-7$

59 Pandian RS, Anuradha CV, Viswanathan P. Gastroprotective effect of fenugreek seeds (Trigonella foenum-graecum) on experimental gastric ulcer in rats. J Ethnopharmacol 2002; 81: $393-7$

60 Raju J, Patlolla JM, Swamy MV, Rao CV. Diosgenin, a steroid saponin of Trigonella foenum-graecum (Fenugreek), inhibits azoxymethane-induced aberrant crypt foci formation in F344 rats and induces apoptosis in HT-29 human colon cancer cells. Cancer Epidemiol Biomarkers Prev 2004; 13: $1392-8$

61 Wang SL, Cai B, Cui CB, Liu HW, Wu CF, Yao XS. Diosgenin-3-O-alpha-Lrhamnopyranosyl-( $1 \rightarrow 4)$-beta-D-glucopyranoside obtained as a new anticancer agent from Dioscorea futschauensis induces apoptosis on human colon carcinoma HCT-15 cells via mitochondria-controlled apoptotic pathway. J Asian Nat Prod Res 2004; 6: 115-25

62 Moalic S, Liagre B, Corbiere C, Bianchi A, Dauca M, Bordji K et al. A plant steroid, diosgenin, induces apoptosis, cell cycle arrest and COX activity in osteosarcoma cells. FEBS Lett 2001; 506: 225 - 30

63 Corbiere C, Liagre B, Bianchi A, Bordji K, Dauca M, Netter P et al. Different contribution of apoptosis to the antiproliferative effects of diosgenin and other plant steroids, hecogenin and tigogenin, on human 1547 osteosarcoma cells. Int J Oncol 2003; 22: 899-905

64 Hibasami H, Moteki H, Ishikawa K, Katsuzaki H, Imai K, Yoshioka Ket al. Protodioscin isolated from fenugreek (Trigonella foenum-graecum $\mathrm{L}$.) induces cell death and morphological change indicative of apoptosis in leukemic cell line H-60, but not in gastric cancer cell line KATO III. Int J Mol Med 2003; 11: $23-6$

65 Liu MJ, Wang Z, Ju Y, Wong RN, Wu QY. Diosgenin induces cell cycle arrest and apoptosis in human leukemia K562 cells with the disruption of Ca2+ homeostasis. Cancer Chemother Pharmacol 2005; 55: 79-90 
66 Leger DY, Liagre B, Corbiere C, Cook-Moreau J, Beneytout JL. Diosgenin induces cell cycle arrest and apoptosis in HEL cells with increase in intracellular calcium level, activation of CPLA2 and COX-2 overexpression. Int J Oncol 2004; 25: 555-62

67 Liagre B, Vergne-Salle P, Corbiere C, Charissoux JL, Beneytout JL. Diosgenin, a plant steroid, induces apoptosis in human rheumatoid arthritis synoviocytes with cyclooxygenase-2 overexpression. Arthritis Res Ther 2004; 6: R373-83

68 Corbiere C, Liagre B, Terro F, Beneytout JL. Induction of antiproliferative effect by diosgenin through activation of $\mathrm{p} 53$, release of apoptosis-inducing factor (AIF) and modulation of caspase-3 activity in different human cancer cells. Cell Res 2004; 14: 188-96

69 Yamada T, Hoshino M, Hayakawa T, Ohhara H, Yamada H, Nakazawa T et al. Dietary diosgenin attenuates subacute intestinal inflammation associated with indomethacin in rats. Am J Physiol 1997; 273: 355 64

70 Nappez C, Liagre B, Beneytout JL. Changes in lipoxygenase activities in human erythroleukemia (HEL) cells during diosgenin-induced differentiation. Cancer Lett 1995; 96: 133-40

71 Ondeykal JG, Herath KB, Jayasuriya H, Polishook JD, Bills GF, Dombrowski $A W$ et al. Discovery of structurally diverse natural product antagonists of chemokine receptor CXCR3. Mol Divers 2005; 9: $123-9$

72 Shishodia S, Aggarwal BB. Diosgenin inhibits osteoclastogenesis, invasion, and proliferation through the downregulation of Akt, I kappa B kinase activation and NF-kappa B-regulated gene expression. Oncogene 2006; 25: 1463 - 73

73 Guo QL, Lin SS, You QD, Gu HY, Yu J, Zhao L et al. Inhibition of human telomerase reverse transcriptase gene expression by gambogic acid in human hepatoma SMMC-7721 cells. Life Sci 2006; 78: 1238-45

74 Zhao L, Guo QL, You QD, Wu ZQ Gu HY. Gambogic acid induces apoptosis and regulates expressions of Bax and Bcl-2 protein in human gastric carcinoma MGC-803 cells. Biol Pharm Bull 2004; 27: 998 - 1003

75 Guo QL, You QD, Zhao L, Gu HY, Yuan ST. Anticancer effect and apoptosis induction of gambogic acid in human gastric cancer line BGC-823. World J Gastroenterol 2005; 11: 3655 -9

76 Yu J, Guo QL, You QD, Lin SS, Li Z, Gu HY et al. Repression of telomerase reverse transcriptase mRNA and hTERT promoter by gambogic acid in human gastric carcinoma cells. Cancer Chemother Pharmacol 2006; 58: $434-43$

77 Yu J, Guo QL, You QD, Zhao L, Gu HY, Yang Y et al. Gambogic acid-induced G2/M phase cell-cycle arrest via disturbing CDK7-mediated phosphorylation of CDC2/p34 in human gastric carcinoma BGC-823 cells. Carcinogenesis 2007; 28: $632-8$

78 Wu ZQ Guo QL, You Q Zhao L, Gu HY. Gambogic acid inhibits proliferation of human lung carcinoma SPC-A1 cells in vivo and in vitro and represses telomerase activity and telomerase reverse transcriptase mRNA expression in the cells. Biol Pharm Bull 2004; 27: 1769-174

79 Kasibhatla S, Essen KA, Maliartchouk S, JWangJY, English NM, Drewe J et al. A role for transferrin receptor in triggering apoptosis when targeted with gambogic acid. Proc Natl Acad Sci U S A 2005; 102: 12 095100

80 Pandey $M K$, Sung B, Ahn KS, Kunnumakkara $A B$, Chaturvedi MM, Aggarwal BB. Gambogic acid, a novel ligand for transferrin receptor, potentiates TNF-induced apoptosis through modulation of the nuclear factor-kappaB signaling pathway. Blood 2007; 110: 3517-25

81 Yi T, Yi Z, Cho SG, Luo J, Pandey MK, Aggarwal BB et al. Gambogic acid inhibits angiogenesis and prostate tumor growth by suppressing vascular endothelial growth factor receptor 2 signaling. Cancer Res 2008; 68: $1843-50$

82 Badary OA, Taha RA, Gamal el-Din AM, Abdel-Wahab MH. Thymoquinone is a potent superoxide anion scavenger. Drug Chem Toxicol 2003; 26: 87-98

83 Badary OA, Abd-Ellah MF, El-Mahdy MA, Salama SA, Hamada FM. Anticlastogenic activity of thymoquinone against benzo(a)pyrene in mice. Food Chem Toxicol 2007; 45: 88-92

84 Mansour MA, Nagi MN, El-Khatib AS, Al-Bekairi AM. Effects of thymoquinone on antioxidant enzyme activities, lipid peroxidation and DTdiaphorase in different tissues of mice: a possible mechanism of action. Cell Biochem Funct 2002; 20: 143 - 51

85 Gali-Muhtasib H, Diab-Assaf M, Boltze C, Al-Hmaira J, Hartig R, Roessner $A$ et al. Thymoquinone extracted from black seed triggers apoptotic cell death in human colorectal cancer cells via a p53-dependent mechanism. Int J Oncol 2004; 25: 857-66
86 Badary OA. Thymoquinone attenuates ifosfamide-induced Fanconi syndrome in rats and enhances its antitumor activity in mice. J Ethnopharmacol 1999; 67: 135-42

87 Badary OA, Gamal El-Din AM. Inhibitory effects of thymoquinone against 20-methylcholanthrene-induced fibrosarcoma tumorigenesis. Cancer Detect Prev 2001; 25: $362-8$

88 Gali-Muhtasib H, Roessner A, Schneider-Stock R. Thymoquinone: a promising anti-cancer drug from natural sources. Int J Biochem Cell Biol 2006; 38: 1249 - 53

89 Roepke M, Diestel A, Bajbouj K, Walluscheck D, Schonfeld P, Roessner A et al. Lack of p53 augments thymoquinone-induced apoptosis and caspase activation in human osteosarcoma cells. Cancer Biol Ther 2007; 6: 160-9

90 Shoieb AM, Elgayyar M, Dudrick PS, Bell JL, Tithof PK. In vitro inhibition of growth and induction of apoptosis in cancer cell lines by thymoquinone. Int J Oncol 2003; 22: 107-13

91 El-Mahdy MA, Zhu Q Wang QE, Wani G, Wani AA. Thymoquinone induces apoptosis through activation of caspase- 8 and mitochondrial events in p53-null myeloblastic leukemia HL-60 cells. Int J Cancer 2005; 117: 409-17

92 Tan M, Norwood A, May M, Tucci M, Benghuzzi H. Effects of (-)epigallocatechin gallate and thymoquinone on proliferation of a PANC-1 cell line in culture. Biomed Sci Instrum 2006; 42: 363 - 71

93 Worthen DR, Ghosheh OA, Crooks PA. The in vitro anti-tumor activity of some crude and purified components of blackseed, Nigella sativa L. Anticancer Res 1998; 18: $1527-32$

94 Mahgoub AA. Thymoquinone protects against experimental colitis in rats. Toxicol Lett 2003; 143: $133-43$

95 Haq A, Lobo PI, Al-Tufail M, Rama NR, Al-Sedairy ST. Immunomodulatory effect of Nigella sativa proteins fractionated by ion exchange chromatography. Int J Immunopharmacol 1999; 21: 283 - 95

96 Hajhashemi V, Ghannadi A, Jafarabadi H. Black cumin seed essential oil, as a potent analgesic and antiinflammatory drug. Phytother Res 2004; 18: $195-9$

97 Badary OA, Nagi MN, al-Shabanah OA, al-Sawaf HA, al-Sohaibani MO, al-Bekairi AM. Thymoquinone ameliorates the nephrotoxicity induced by cisplatin in rodents and potentiates its antitumor activity. Can J Physiol Pharmacol 1997; 75: 1356-61

98 Badary OA, Al-Shabanah OA, Nagi MN, Al-Rikabi AC, Elmazar MM. Inhibition of benzo[a]pyrene-induced forestomach carcinogenesis in mice by thymoquinone. Eur J Cancer Prev 1999; 8: 435-40

99 El Mezayen E, El Gazzar M, Nicolls MR, JMarecki JC, Dreskin SC, Nomiyama $\mathrm{H}$. Effect of thymoquinone on cyclooxygenase expression and prostaglandin production in a mouse model of allergic airway inflammation. Immunol Lett 2006; 106: $72-81$

100 Nagi MN, Mansour MA. Protective effect of thymoquinone against doxorubicin-induced cardiotoxicity in rats: a possible mechanism of protection. Pharmacol Res 2000; 41: 283 -9

101 El-Mahmoudy A, Matsuyama H, Borgan MA, Shimizu Y, El-Sayed MG, Minamoto $N$ et al. Thymoquinone suppresses expression of inducible nitric oxide synthase in rat macrophages. Int Immunopharmacol 2002; 2: 1603-11

102 El-Dakhakhny M, Madi NJ, Lembert N, Ammon HP. Nigella sativa oil, nigellone and derived thymoquinone inhibit synthesis of 5-lipoxygenase products in polymorphonuclear leukocytes from rats. J Ethnopharmacol 2002; 81: $161-4$

103 El-Mahmoudy A, Shimizu Y, Shiina T, Matsuyama H, Nikami H, Takewaki T. Macrophage-derived cytokine and nitric oxide profiles in type I and type II diabetes mellitus: effect of thymoquinone. Acta Diabetol 2005; 42: $23-30$

104 Gali-Muhtasib HU, Abou Kheir WG, Kheir LA, Darwiche N, Crooks PA. Molecular pathway for thymoquinone-induced cell-cycle arrest and apoptosis in neoplastic keratinocytes. Anticancer Drugs 2004; 15: 389-99

105 Sethi G, Ahn KS, Aggarwal BB. Targeting NF-kB activation pathway by thymoquinone: role in suppression of antiapoptotic gene products and enhancement of apoptosis. Mol Cancer Res, in press

106 Yi T, Yi Z, Cho S, Pang X, Rodriguez M, Wang Y et al. Thymoquinone inhibits tumor angiogenesis and tumor growth through suppressing AKT and ERK signaling pathways. Mol Cancer Ther, in press

107 Huang MT, Ho CT, Wang ZY, Ferraro T, Lou YR, Stauber K et al. Inhibition of skin tumorigenesis by rosemary and its constituents carnosol and ursolic acid. Cancer Res 1994; 54: 701 -8 
108 Tokuda H, Ohigashi H, Koshimizu K, Ito Y. Inhibitory effects of ursolic and oleanolic acid on skin tumor promotion by 12-O-tetradecanoylphorbol 13-acetate. Cancer Lett 1986; 33: $279-85$

109 Ohigashi H, Takamura H, Koshimizu K, Tokuda H, Ito Y. Search for possible antitumor promoters by inhibition of 12-O-tetradecanoylphorbol 13-acetate-induced Epstein-Barr virus activation; ursolic acid and oleanolic acid from an anti-inflammatory Chinese medicinal plant, Glechoma hederaceae L. Cancer Lett 1986; 30: 143-51

110 Nishino H, Nishino A, Takayasu J, Hasegawa T, Iwashima A, Hirabayash $K$ et al. Inhibition of the tumor-promoting action of 12-O-tetradecanoylphorbol 13-acetate by some oleanane-type triterpenoid compounds. Cancer Res 1988; 48: 5210-5

111 Sohn KH, Lee HY, Chung HY, Young HS, Yi SY, Kim KW. Anti-angiogenic activity of triterpene acids. Cancer Lett 1995; 94: $213-8$

112 Simon A, Najid A, Chulia AJ, Delage C, Rigaud M. Inhibition of lipoxygenase activity and HL60 leukemic cell proliferation by ursolic acid isolated from heather flowers (Calluna vulgaris). Biochim Biophys Acta 1992; 1125: $68-72$

113 Najid A, Simon A, Cook J, Chable-Rabinovitch H, Delage C, Chulia AJ et al. Characterization of ursolic acid as a lipoxygenase and cyclooxygenase inhibitor using macrophages, platelets and differentiated HL60 leukemic cells. FEBS Lett 1992; 299: 213 -7

114 Ringbom T, Segura L, Noreen Y, Perera P, Bohlin L. Ursolic acid from Plantago major, a selective inhibitor of cyclooxygenase-2 catalyzed prostaglandin biosynthesis. J Nat Prod 1998; 61: 1212 -5

115 Subbaramaiah K, Michaluart P, Sporn MB, Dannenberg AJ. Ursolic acid inhibits cyclooxygenase- 2 transcription in human mammary epithelial cells. Cancer Res 2000; 60: 2399-404

116 Cha HJ, Bae SK, Lee HY, Lee OH, Sato H, Seiki M et al. Anti-invasive activity of ursolic acid correlates with the reduced expression of matrix metalloproteinase-9 (MMP-9) in HT1080 human fibrosarcoma cells. Cancer Res 1996; 56: 2281 - 4

117 Cha HJ, Park MT, Chung HY, Kim ND, Sato H, Seiki M et al. Ursolic acidinduced down-regulation of MMP-9 gene is mediated through the nuclear translocation of glucocorticoid receptor in HT1080 human fibrosarcoma cells. Oncogene 1998; 16: $771-8$

118 Es-Saady D, Simon A, Jayat-Vignoles C, Chulia AJ, Delage C. MCF-7 cell cycle arrested at G1 through ursolic acid, and increased reduction of tetrazolium salts. Anticancer Res 1996; 16: 481 -6

119 Es-Saady D, Simon A, Ollier M, Maurizis JC, Chulia AJ, Delage C. Inhibitory effect of ursolic acid on B16 proliferation through cell cycle arrest. Cancer Lett 1996; 106: $193-7$

120 Choi BM, Park R, Pae HO, Yoo JC, Kim YC, Jun CD et al. Cyclic adenosine monophosphate inhibits ursolic acid-induced apoptosis via activation of protein kinase A in human leukaemic HL-60 cells. Pharmacol Toxicol 2000; 86: $53-8$

121 Choi YH, Baek JH, Yoo MA, Chung HY, Kim ND, Kim KW. Induction of apoptosis by ursolic acid through activation of caspases and downregulation of c-IAPs in human prostate epithelial cells. Int J Oncol 2000; $17: 565-71$

122 Hollosy F, Meszaros G, Bokonyi G, Idei M, Seprodi A, Szende B et al. Cytostatic, cytotoxic and protein tyrosine kinase inhibitory activity of ursolic acid in A431 human tumor cells. Anticancer Res 2000; 20: $4563-70$
123 Hollosy F, Idei M, Csorba G, Szabo E, Bokonyi G, Seprodi A et al. Activation of caspase- 3 protease during the process of ursolic acid and its derivative-induced apoptosis. Anticancer Res 2001; 21: 3485-91

124 Konopleva M, Tsao T, Ruvolo P, Stiouf I, Estrov Z, Leysath CE et al. Novel triterpenoid CDDO-Me is a potent inducer of apoptosis and differentiation in acute myelogenous leukemia. Blood 2002; 99: 326 - 35

125 Kim DK, Baek JH, Kang CM, Yoo MA, Sung JW, Chung HY et al. Apoptotic activity of ursolic acid may correlate with the inhibition of initiation of DNA replication. Int J Cancer 2000; 87: 629-36

126 Baek JH, Lee YS, Kang CM, Kim JA, Kwon KS, Son HC et al. Intracellular $\mathrm{Ca} 2+$ release mediates ursolic acid-induced apoptosis in human leukemic HL-60 cells. Int J Cancer 1997; 73: 725 -8

127 Lauthier F, Taillet L, Trouillas P, Delage C, Simon A. Ursolic acid triggers calcium-dependent apoptosis in human Daudi cells. Anticancer Drugs 2000; 11: 737-45

128 Shishodia S, Majumdar S, Banerjee S, Aggarwal BB. Ursolic acid inhibits nuclear factor-kappaB activation induced by carcinogenic agents through suppression of IkappaBalpha kinase and p65 phosphorylation: correlation with down-regulation of cyclooxygenase 2, matrix metalloproteinase 9, and cyclin D1. Cancer Res 2003; 63: 4375 - 83

129 Pathak AK, Bhutani M, Nair AS, Ahn KS, Chakraborty A, Kadara H et al. Ursolic acid inhibits STAT3 activation pathway leading to suppression of proliferation and chemosensitization of human multiple myeloma cells. Mol Cancer Res 2007; 5: $943-55$

130 Shukla Y, Prasad S, Tripathi C, Singh M, George J, Kalra N. In vitro and in vivo modulation of testosterone mediated alterations in apoptosis related proteins by [6]-gingerol. Mol Nutr Food Res 2007; 51: $1492-502$

131 Ishiguro K, Ando T, Maeda O, Ohmiya N, Niwa Y, Kadomatsu $K$ et al. Ginger ingredients reduce viability of gastric cancer cells via distinct mechanisms. Biochem Biophys Res Commun 2007; 362: 218 - 23

132 Lee HS, Seo EY, Kang NE, Kim WK. [6]-Gingerol inhibits metastasis of MDA-MB-231 human breast cancer cells. J Nutr Biochem 2008; 19: $313-9$

133 Bode AM, Ma WY, Surh YJ, Dong Z. Inhibition of epidermal growth factor-induced cell transformation and activator protein 1 activation by [6]-gingerol. Cancer Res 2001; 61: 850-3

134 Kim EC, Min JK, Kim TY, Lee SJ, Yang HO, Han S et al. [6]-Gingerol, a pungent ingredient of ginger, inhibits angiogenesis in vitro and in vivo. Biochem Biophys Res Commun 2005; 335: 300-8

135 Kim SO, Chun KS, Kundu JK, Surh YJ. Inhibitory effects of [6]-gingerol on PMA-induced COX-2 expression and activation of NF-kappaB and p38 MAPK in mouse skin. Biofactors 2004; 21: 27-31

136 Lee SH, Cekanova M, Baek SJ. Multiple mechanisms are involved in 6gingerol-induced cell growth arrest and apoptosis in human colorectal cancer cells. Mol Carcinog 2008; 47: 197-208

137 Patel D, Shukla S, Gupta S. Apigenin and cancer chemoprevention: progress, potential and promise (review). Int J Oncol 2007; 30: $233-45$

138 Manju V, Nalini N. Protective role of luteolin in 1,2-dimethylhydrazine induced experimental colon carcinogenesis. Cell Biochem Funct 2007: $25: 189-94$ 